\title{
XLVII. Some remarks upon an urinary calculus having a cinder as its nucleus; with a notice of other calculi containing a small quantity of carbonate of lime. The occurrence also of brown spar, noticed in the trap rock near Newport in Gloucestershire
}

\section{Richard Smith}

To cite this article: Richard Smith (1817) XLVII. Some remarks upon an urinary calculus having a cinder as its nucleus; with a notice of other calculi containing a small quantity of carbonate of lime. The occurrence also of brown spar, noticed in the trap rock near Newport in Gloucestershire, Philosophical Magazine Series 1, 49:227, 188-191, DOI: $10.1080 / 14786441708637878$

To link to this article: http://dx.doi.org/10.1080/14786441708637878

Published online: 27 Jul 2009.

Submit your article to this journal $\llbracket$

山ll Article views: 2 
place 1 opposite to 64 ; and against the divisor 2 will stand the quotient 32 . Given 4,8 , and 8 , to find a fourth proportional :place 8 opposite to 8 ; against 4 is found 16 . To find the factors of 64 :-bring 1 to that number; in this position of the scale every factor will be found opposite to its reciprocal ; as 2 against 32,4 against 16,8 against 8 , which is consequently the square root of the given number. Or, if the factors of 640 be required, the same position of the slide shows that $2 \times 320,4 \times 160$, $5 \times 128,8 \times 80,10 \times 64,16 \times 40$, and $20 \times 32$, equally produce that number; whilst the juxtaposition of $25 \cdot 3$ in both lines shows that to be its root with as much accuracy as can be expected from so short a radius.

The scale reduced in length in the manner above described, but without the inversion of either of its lines, is competent to the solution of all questions of simple multiplication or division; and in this form it is prepared for the use of the officers of the Excise by R. B. Bate, of the Poultry, the accuracy and neatness of whose workmanship I cannot avoid mentioning, though I am sensible they are too well known to derive any publicity from this notice of them.

Feb. 8, 1817.

Silvanus Bevan.

XLVII. SomeRemarks upon an urinary Calculus having a Cinder: as its Nucleus; with a Notice of other Calculi containing a small Quantity of Carlonate of Lime. The occurrence also of Brown Spar, noticed in the Trap Ruck near Newport in Gloucestershire.

To Mr. Tilloch.

Sir, - $\mathrm{H}_{\text {AviNg seen in one of your late numbers an account }}$ of an urinary calculus chiefly composed of carbonate of lime, I have been induced to send you the following particulars of a calculus composed likewise of carbonate of lime, and further interesting from the substance forming its nucleus.

This substance is a common cinder, and it constitutes the greater part of the specimen. Although it is impossible to mistake its appearance, I may observe that sulph. acid when treated with a very small quantity of it very soon acquired a dark-brown colour. The cinder is surrounded but not intermixed with a layer of a yellowish-white colour, which dissolves in nuriatic acid with a brisk effervescence, leaving behind a few tender flocculi. The solution being treated with subcarbonate of potash yielded carbonate of lime nearly to the amount of the original quantity employed; viz. two grains. To certify the presence of carbonic acid, I put a very small quantity of the calculus in a two-dram bottle, which immediately upon being filled with a di- 
lute acid and covered with a small bit of glass, was quickly inverted so as to stand upon the glass. In this way the bottle soon became flled with gas, which, upon being transferred into a small tube of lime-water and agitated in it, was quickly absorbed, rendering at the same time the lime-water milky. Hence the earthy part of the calculus is chiefly composed of carbonate of lime inixed with a little animal nembrane. The exterior surface of the calculus is of a brown colour, and presents that kind of uneven appearance usuaily seen in mulberry calculi. The brown coating, however, is quite superficial, and is probably derived from animal matter, as I could find no trace of uric acid. Curious as the structure of this specimen is, I regret that the history of it is extremely obscure. It belongs to my friend Mr. Richard Smith senior, surgeon to the Bristol Infirmary, whose account of it 1 have transmitted to you.

Any one from its figure and appearance might consider it as a human calculus; but it is hardly possible to conceive how a cinder of this size could have been introduced into the bladder either of a male or female: besides which, the non-existence of uric acid which is generally present in some proportion or other in human calculi, and the fact of its being composed of carbonate of line, - a very common ingredient in animal calculi, but a rare one in those of the human bladder,-are consideratious very contradictory to this idea. May not the cinder have been wantonly thrust into the bladder of a cow or some other animal, and in this way have given origin to the present concretion?

I recollect Mr. Brande, in a paper of his in the Philosophical Transactions, speaks of several human urinary calculi having extraneous bodies for their nuclei, one of which was an hazel nut.

Having had free access to the extensive collection of $\mathrm{Mr}$. Richard Smith, and having gone through the analysis of a variety of specimens, I nray here take an opportunity of stating that I have met with three calculi, all human, which contained a small admixture of carbonate of lime. In dissolving a calculus (which I had reason to believe one of the ammoniaco-magnesian phosphates) in acetic acid, I was surprised at seeing a slow effervescence take place, which I found by the expedient above described to proceed from the disengagement of carbonic acid. The proportion of carbonate of lime was discovered by dissolving a few grains of it in dilute muriatic acid. To the solution pure ammonia was added, which threw down the phosphates of lime, ammonia and magnesia: these being separated, the solution was treated with carbonate of potash, and in anotber experiment with oxalate of ammonia, both of whicl gave a distinct precipitate. 
The analysis of 11 ta grains of this calculus, conducted other wise in the usual way, gave me

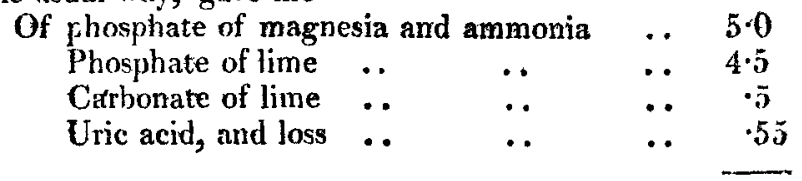

$11 \cdot 75$

In another calculus principally composed of the ammoniacomagnesian phosphate, the proportion of carbonate of lime was only half the above quantity; and in a third it was still less. I wish particularly to mention these instances of the occurrence of earbonate of lime, because Dr. Henry in his invalwable work (Elements of Chemistry) calls in question the authority of Proust, in giving carbonate of lime as an ingredient in urinary calculi.

1 have seen somewhere a notice of Mr. Bakewell having discovered prehnite in the trap rock of Micklewood near Newport, Gloucestershire. I regret that the particular spot is not mentioned as I (among many others who have examined the hill) am extremely curious to know the exact locality. This rock is highly interesting, as it exhibits great variety in its structure; being sometimes a sort of iron clay, sometimes trap tuff, in another place exhibiting globular concretions of basaltic clinkstone; but the greater part of it is an amygdaloid consisting genterally of a basis of iron clay, in which are oval concretions of green earth, and of a mineral of a white and brown colour resembling calc spar, and which has been by many mistaken as such. I have fomd the same substance in veins in the rock, and upon analysis I find that it is the mineral called brown spar, and contains 44 per cent. of carbonate of magnesia. I am, sir, Very respectfully yours, York Crescent, Clifton. W. H. Gruby, M.D. *** Very well-executed drawings of the "cinder calculus" accompanied Dr. Gilby's communication; but being coloured, we cannot with convenience give an engraving of its figure, \&c. In its longet diameter it is about two inches; in its shortest about one inch and a quarter. The drawings will be taken care of for Dr. G.

\section{Mr. SMith's Letter to Dr. Guiby.}

MY Dear Sir,-The " cinder calculus" was given to me by Mr. B. G. Burroughs of Clifton, about a year since. Being in the habit of cxtting them through, in order to exhibit the nuclens, I was not a little surprised to observe the saw in this case covered 
covered with a black matter, and still more so when I found the strange substance of which it was chiefly composed, I became of course extremely anxious to learn its history. But this is all that I could obtain from $\mathrm{Mr}$. B. "That it had been in his possession four or five years, and that the person who gave it to him told him that it was extracted by a Mr. Pye, and Mr. B. did not doubt that a human subject was implied."

Some gentlemen who have seen it imagine that it might have been taken from a watering-place in a street: but I have submitied substances to a trial of pouring urine upon them, and find the appearance entirely different. In the latter instances there is an even uniform stratum super stratum; whereas in this calculus there is a distinct tubercular appearance, resembling those denominated mulberry. Again: in the one case the lavers are tender and easily brushed off, but here they are excessively frim.

One circumstance is not unworthy of remark, which is-that out of more than one hundred and fifty sets of calcuil in my museum, this is the only one with the tubercular appearance which does not contain oxalic acid.

98, Park Strect. I remain, dear sir, yours truly,

To Dr. W.H.Gilly.

Richatd SMTitr.

This calculus certainly contains no nxalate of lime, as it dissolves completely in dilute acetic acid; whereas oxalate of lime is insoluble in that acid.

XLVIII. Alstract of "Instruction concerning the Making of Bread from damaged Corn. Framed by a special Commission named by His Excellency the Secretary of State for the Department of the Interior, und composed of Messrs. Gav, How norary Counsellor of Siate, President; Mores. de VINDE, Peer of France; St. Martin, Commissary General of Hos pilals; Bosc, Yvart, Thenard, Gay Lussac and SilVEsTre (Secretary), Members of the Royal Academy of Sciences." Published 28th Fel. 1817.

$T$ He continual rains which have fallen this year during the months of July, August, and September*, have rendered the labours of the harvest difficult, and have affected a part of its produce.

* In the months of July and August 1816, nhout three times as much rain, and in the month of September about twice as much, fell, as in the corresponding months of the year 1815 . The mean tempenature for the nine first months of 1816 was two degrees less than that of the nine first months of $181 j$. 